\title{
Assessment of knowledge and attitude of married women regarding masturbation risks.
}

\author{
Nariman Mohamed shafea mansour ${ }^{1}$, Nadia Mohamed fahmy ${ }^{2}$, Soad Abd El \\ Salam Ramadan ${ }^{3}$, Hanan Amin Gaafer ${ }^{4}$ \\ ${ }^{1}$ Specialist nurse in Benha university hospital, ${ }^{2}$ Nursing Maternity and Neonatal Department, \\ Faculty of Nursing, Ain Shams University, Cairo, Egypt ${ }^{34}$ Nursing Maternity and Neonatal \\ Department, Faculty of Nursing, Benha University, Egypt
}

\begin{abstract}
Masturbation is a relatively neglected topic in research.Therefore the purpose of the study was to assess knowledge and attitude of married women regarding masturbation risks SETTING: The out-patient clinic in Obstetric and Gynecological department at Benha university hospital DESIGN:A descriptive research design was utilized. SAMPLING: AConvenient sample of married women, total number is 334 women. Instruments: two instruments were utilized for data collection, Astructured- interviewing questionnaire sheet for knowledge about masturbation and its risks and a modified Likert scale for attitude of married women regarding masturbation risks. RESULTS: indicates that there was a highly positive association between the studied women total knowledge score and attitude scores $(\mathrm{p}<0.001)$.CONCLUSION: : the majority of studied women had poor knowledge about masturbation and its risks and nearly three quarters of them had negative attitude regarding masturbation and its risks.. RECOMMENDATION: provide educational program including married women for arising the awareness of masturbation and its risks
\end{abstract}

Key words: masturbation, knowledge, attitude and risks.

\section{Introduction}

Masturbation is ahuman practice and an expression of sexual outlet related to the beginning of sexual development, it is also called an orgasmic experience. It is an act of exciting sexual organs by stroking, pressing, rubbing or other forms of manipulation, It is controlled by three factors: hormonal, environmental and emotional factors (Kabbash et al., 2017).

A lot of studies were carried out in developed countries to assess the prevalence and factors contributing to masturbation and sexual fantasy. On the other hand, data from developing countries is lacking. In Egypt, few studies handled these sensitive topics. One of these studies was an old study carried out in 1999 on 163 wives with sexual dysfunction. The study found that $3.1 \%$ of the wives had excessive masturbation. Another study was done in 2000 and reported that $2.86 \%$ of circumcised wives had excessive masturbation (kasemy et al., 2016).

Negative societal implications to masturbation

Despite its apparent widespread prevalence, masturbation is a highly stigmatized topic viewed negatively across settings. In research on sexual behavior, masturbation is the among the most sensititve topics and underreported by adolescents even with the use of confidential reportig technique. In the world's major religions, guilt, shame, and indulgence continue to be themes all religions associate with masturbation (Moawad, 2015).

\section{Purpose of the study}

To assess knowledge and attitude of married women regarding masturbation risks.

\section{Research question:}


- What is the knowledge of married women about masturbation risks?

- What is the attitude of married women regarding masturbation risks?

- Is there correlation between the knowledge and attitude of married women regarding masturbation risks?

\section{Research design:}

A descriptive design has been adopted to fulfill the purpose of the present study.

\section{Study setting:}

The study was conducted in out-patient clinic in Obstetric and Gynecological department at Benha university hospital

\section{Sampling:}

Target population: married women

Sample type: Convenient sample.

- Size and technique: sample size was calculated based on the annul flow rate of women at studied for year (20162017)

- It was 2000 women

- The sample size was calculated through the following sample equation:

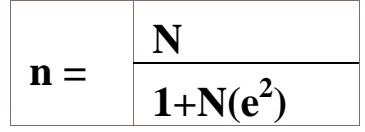

$$
\begin{aligned}
& \text { - } \mathrm{n}=\text { sample } \mathrm{N}=\text { The whole }
\end{aligned}
$$

\section{Instrument of data collection}

Tools were used to collect data

Tool (I) A structured- interviewing questionnaire; designed by the researcher .It was included the following:

- Part 1: Socio- demographic data as (age, level of women education, years of marriage, husband education, husband occupation, women occupation, number of children, They were composed of (18) items
- Part 2: It was used to assess women knowledge about masturbation and masturbation risks. all question were written in simple Arabic language. The questions in the form of: Closed ended questions

Tool (II) Modified likert scale; adapted from Moawad, 2015 and then developed by the researcher.

It was statement was used to assess attitude of married women about masturbation and it's risks

\section{procedure:}

1) An official letter requesting permission included the title and the aim of the study to conduct the study was submitted from dean of Benha faculty of nursing directed to director official of Benha university hospital.

2) The process of data collection was carried out from the beginning of June (2017) to the end of December (2017).

- The study conducted by the researcher for married women in outpatient clinic in obstetric and gynecological department at Benha university hospital.

- The researcher met the women three days in week (Sunday-TuesdayThursday) from 8 am to $1 \mathrm{pm}$

- In each time, the following steps were done:

- Greeting the married women.

- Explaining the purpose and the aim and the method of filling the tool of the study to each participant.

- Obtain oral consent.

3) Before collecting data, researcher took the participant to isolated corner beside the clinic.

4) The researcher interviewed each woman alone using the questions in structured -interviewing questionnaire which include: 
5) Socio -demographic data and knowledge assessment and it consume 45minutes.

6) Finally (modified likert scale) were used to assess attitude of women regarding masturbation and it's risks and it consume 30 minutes.

7) Researcher took around 5 women in day.

8) These steps were carried out with each visit until the sample size is completed

\section{Data analysis:}

An IBM compatible personal computer was used to store and analyze data and to produce graphic presentation for some results .Statistical package for the social science (SPSS) version (22) was used for statistical analysis of data, as it contains the test of significance given in standard statistical books.

Data were summarized using 1)the arithmetic mean as an average, describing the central tendency of observation for each variable studied;2)the standard deviation as a measure of dispersion of results around the mean; and 3)the frequency and percentage of observations for each variable studied. Other statistical tests such as chi - square test were calculated between socio-demographic data and total knowledge score and between total knowledge score and total attitude score.

For all statistical tests done, the threshold of significance was fixed at the 5\%level (P-Value).A p -value $>0.05$ indicates non - significant result and the $\mathrm{p}$ - value $<0.05$ indicates a significant result and the $\mathrm{p}-$ value is the degree of significance. The smaller the $\mathrm{p}$ - value obtained, the more significant is the result; the $\mathrm{p}$ - value being the probability of error of the conclusion

\section{RESULTS}

Table (1): shows that near half of the studied women age ranged between (2030) years old, with the mean of
$(28.67 \pm 9.62)$ years old. The vast majority of them were married, $39.2 \%$ of them married for about (1-5 years).in addition $38.6 \%$ of them had a secondary level of education, and $66.5 \%$ of them were recruited at rural setting.

Table (2): reveals that $53.3 \%, 49.7 \%$, $37.7 \%$ of the studied women had inadequate knowledge regarding effect of education on masturbation, Preventive measures of masturbation, and feeling affecting female during practice masturbation interruption respectively. On the other hand $82.9 \%, 66.5 \%$, and $57.2 \%$ of them had adequate knowledge regarding effect of masturbation on sexual relation among married women, Persons practice masturbation and masturbator Female feeling toward marital relationship respectively.

Table (3): reveals that $82.0 \%, 74.9 \%$ and $71.8 \%$ of the studied women disagreed that practice of women to masturbation makes them happier than the marital relationship, Talk about masturbation with your friends, and Water tap direct toward clitoral is one of the ways to practice masturbation respectively. On the other hand $85.3 \%, 77.5 \%$, and $68.0 \%$ of them agreed that The Internet contributes significantly to obtaining this type of information easily, It is important to develop educational curricula about masturbation and it's risks and Every mother is responsible for educating her daughters about the risks of masturbation respectively

Table (4): shows that there was a highly statistical significant difference among the studied women total knowledge score and their age, marital status, educational qualification, occupational status, and residence $(\mathrm{p}<0.001 * *)$.As the highest total knowledge mean score was among women at age group from (40-50) years old, married women, women with graduate level of education, employed women, and women lived urban setting. 
Table (5): shows that there was a highly statistical significant difference among the studied women total knowledge score and their age, marital status, educational qualification, and residence $\left(\mathrm{p}<0.001^{* *}\right)$. As the highest total attitude mean score was among women at age group from (40-50) years old, married women, women with graduate level of education, employed women, and women lived urban setting.
Table (6): indicates that there was a highly positive association between the studied women total knowledge score and attitude scores $\left(\mathrm{p}<0.001^{* *}\right)$.

Figure (1): percentage distribution of the studied women regarding their resources about masturbation knowledge.

Figure (2): percentage distribution of the studied women regarding their total attitude.

\section{Part I: Socio-Demographic data}

Table (1): Distribution of general characteristics of the studied women $(n=334)$.

\begin{tabular}{|c|c|c|}
\hline Variable & Frequency & $\%$ \\
\hline \multicolumn{3}{|l|}{ Age in years } \\
\hline $20-29$ & 161 & 48.2 \\
\hline $30-39$ & 116 & 34.7 \\
\hline $40-50$ & 57 & 17.1 \\
\hline Mean \pm SD & \multicolumn{2}{|c|}{$28.67 \pm 9.62$} \\
\hline \multicolumn{3}{|l|}{ Marital status } \\
\hline Married & 308 & 92.2 \\
\hline Divorced & 26 & 7.8 \\
\hline \multicolumn{3}{|l|}{ widow } \\
\hline \multicolumn{3}{|l|}{ Years of marriage } \\
\hline Less than one year & 63 & 18.9 \\
\hline $1-5$ years & 131 & 39.2 \\
\hline More than 5 years & 140 & 41.9 \\
\hline Mean \pm SD & \multicolumn{2}{|c|}{$4.84 \pm 2.34$} \\
\hline \multicolumn{3}{|c|}{ Educational qualification } \\
\hline Illiterate & 58 & 17.4 \\
\hline Read and writ & 59 & 17.7 \\
\hline Secondary & 129 & 38.6 \\
\hline Graduate & 88 & 26.3 \\
\hline \multicolumn{3}{|l|}{ Occupation } \\
\hline House wife & 133 & 39.8 \\
\hline Craft women & 17 & 5.1 \\
\hline employer & 184 & 55.1 \\
\hline \multicolumn{3}{|l|}{ Residence } \\
\hline Rural & 222 & 66.5 \\
\hline Urban & 112 & 33.5 \\
\hline
\end{tabular}

Table (2): Distribution of the studied women knowledge regarding masturbation $(n=334)$.

\begin{tabular}{|l|c|c|c|c|c|c|}
\hline \multirow{2}{*}{ Knowledge } & \multicolumn{2}{|c|}{ Don't know } & \multicolumn{2}{c|}{ Inadequate } & \multicolumn{2}{c|}{ Adequate } \\
\cline { 2 - 7 } & $\mathbf{N o}$ & $\mathbf{\%}$ & $\mathbf{N o}$ & $\mathbf{\%}$ & No & $\%$ \\
\hline Definition of masturbation & 51 & 15.3 & 106 & 31.7 & 177 & 53.0 \\
\hline Persons practice masturbation & 86 & 25.7 & 26 & 7.8 & 222 & 66.5 \\
\hline Motives for female masturbation & 35 & 10.5 & 173 & 51.8 & 126 & 37.7 \\
\hline Age of practice masturbation & 34 & 10.2 & 201 & 60.2 & 99 & 29.6 \\
\hline Educational level affecting masturbation & 178 & 53.3 & 41 & 12.3 & 115 & 34.4 \\
\hline Residence affecting masturbation & 106 & 31.7 & 172 & 51.5 & 56 & 16.8 \\
\hline Causes of young female for masturbation & 80 & 24.0 & 115 & 34.4 & 139 & 41.6 \\
\hline $\begin{array}{l}\text { Feeling affecting female during practice } \\
\text { masturbation interruption }\end{array}$ & 126 & 37.7 & 71 & 21.3 & 137 & 41.0 \\
\hline Action toward feeling affecting female & 100 & 29.9 & 194 & 58.1 & 40 & 12.0 \\
\hline Causes of married women for masturbation & 44 & 13.2 & 164 & 49.1 & 126 & 37.7 \\
\hline Effect of masturbation on sexual relation among & 1 & .3 & 56 & 16.8 & 277 & 82.9 \\
\hline
\end{tabular}




\begin{tabular}{|l|l|l|l|l|l|l|}
\hline married women & & & & & & \\
\hline $\begin{array}{l}\text { Masturbator Female feeling toward marital } \\
\text { relationship }\end{array}$ & 74 & 22.2 & 69 & 20.6 & 191 & 57.2 \\
\hline Opinion of islam regarding female masturbation & 69 & 20.7 & 115 & 34.4 & 150 & 44.9 \\
\hline Preventive measures of masturbation & 166 & 49.7 & 110 & 32.9 & 58 & 17.4 \\
\hline Complication of masturbation & 22 & 6.6 & 156 & 46.7 & 156 & 46.7 \\
\hline Effect of masturbation on psychological status & 23 & 6.9 & 258 & 77.2 & 53 & 15.9 \\
\hline
\end{tabular}

Table (3): Distribution of the studied women attitude regarding masturbation $(n=334)$.

\begin{tabular}{|c|c|c|c|c|c|c|}
\hline \multirow[t]{2}{*}{ items } & \multicolumn{2}{|c|}{ Disagree } & \multicolumn{2}{|c|}{ Uncertain } & \multicolumn{2}{|c|}{ Agree } \\
\hline & No & $\%$ & No & $\%$ & No & $\%$ \\
\hline "masturbation" is a physical need for women? & 135 & 40.4 & 6 & 1.8 & 193 & 57.8 \\
\hline $\begin{array}{l}\text { Masturbation is one of the most prevalent topics in the } \\
\text { past? }\end{array}$ & 71 & 21.2 & 81 & 24.3 & 182 & 54.5 \\
\hline $\begin{array}{l}\text { The spread of masturbation at present is partly due to } \\
\text { the media and the presence of more details such as } \\
\text { pictures and video about this problem? }\end{array}$ & 0 & 0.0 & 113 & 33.8 & 221 & 66.3 \\
\hline $\begin{array}{l}\text { The Internet contributes significantly to obtaining this } \\
\text { type of information easily? }\end{array}$ & 0 & 0.0 & 49 & 14.7 & 285 & 85.3 \\
\hline $\begin{array}{l}\text { Females are more practice to masturbation of the } \\
\text { present? }\end{array}$ & 17 & 5.1 & 179 & 53.6 & 138 & 41.3 \\
\hline $\begin{array}{l}\text { There are many women watching pornography such as } \\
\text { video clips or video clips. }\end{array}$ & 33 & 9.9 & 167 & 50.0 & 134 & 40.1 \\
\hline $\begin{array}{l}\text { Pillow between the legs sleeping providing the female } \\
\text { feeling of desire in the practice of the secret? }\end{array}$ & 110 & 32.9 & 93 & 27.8 & 131 & 39.2 \\
\hline Isolation provides a sense of masturbation? & 80 & 24.0 & 78 & 23.3 & 176 & 52.7 \\
\hline Masturbation practice provides a feeling of depression & 95 & 28.4 & 65 & 19.5 & 174 & 52.1 \\
\hline $\begin{array}{l}\text { The practice of female to masturbation is effective in } \\
\text { solving problems and pressures? }\end{array}$ & 183 & 54.8 & 82 & 24.6 & 69 & 20.6 \\
\hline $\begin{array}{l}\text { Tight clothes, especially - pants, increase the desire to } \\
\text { practice masturbation for the female? }\end{array}$ & 164 & 49.1 & 35 & 10.5 & 135 & 40.4 \\
\hline $\begin{array}{l}\text { Watertap direct toward clitoral is one of the ways to } \\
\text { practice masturbation? }\end{array}$ & 240 & 71.8 & 46 & 13.8 & 48 & 14.4 \\
\hline Masturbation for females leads to infertility & 185 & 55.4 & 149 & 44.6 & 0 & 0.0 \\
\hline $\begin{array}{l}\text { Female practice of secret practice leads to } \\
\text { transmission of infection to the genitals }\end{array}$ & 82 & 24.5 & 211 & 63.2 & 41 & 12.3 \\
\hline Female practice of masturbation lead to un virgin & 152 & 45.5 & 144 & 43.1 & 38 & 11.4 \\
\hline Female practice of masturbation leads to bleeding & 69 & 20.7 & 153 & 45.8 & 112 & 33.5 \\
\hline Masturbation leads to cancer & 118 & 35.3 & 176 & 52.7 & 40 & 12.0 \\
\hline $\begin{array}{l}\text { Masturbation leads to change the shape of the female } \\
\text { external member }\end{array}$ & 129 & 38.6 & 130 & 38.9 & 75 & 22.5 \\
\hline $\begin{array}{l}\text { Women's practice of masturbation protects them } \\
\text { against sexually transmitted diseases }\end{array}$ & 55 & 16.5 & 140 & 41.9 & 139 & 41.6 \\
\hline $\begin{array}{l}\text { The fungal infections in the female genitalia are a } \\
\text { cause of masturbation? }\end{array}$ & 129 & 38.6 & 91 & 27.3 & 114 & 34.1 \\
\hline $\begin{array}{l}\text { after practice of masturbation the female feeling } \\
\text { ashamed? }\end{array}$ & 95 & 28.4 & 77 & 23.1 & 162 & 48.5 \\
\hline Masturbation affects social life? & 87 & 26.0 & 79 & 23.7 & 168 & 50.3 \\
\hline The practice of the female to masturbation is harmful? & 49 & 14.6 & 80 & 24.0 & 205 & 61.4 \\
\hline $\begin{array}{l}\text { The practice of women to masturbation makes them } \\
\text { happier than the marital relationship? }\end{array}$ & 274 & 82.0 & 24 & 7.2 & 36 & 10.8 \\
\hline $\begin{array}{l}\text { Discuss the subject of masturbation topic with your } \\
\text { mother? }\end{array}$ & 213 & 63.8 & 64 & 19.2 & 57 & 17.1 \\
\hline $\begin{array}{l}\text { Every mother is responsible for educating her } \\
\text { daughters about the risks of masturbation? }\end{array}$ & 83 & 24.8 & 24 & 7.2 & 227 & 68.0 \\
\hline Talk about masturbation with your friends & 250 & 74.9 & 49 & 14.6 & 35 & 10.5 \\
\hline $\begin{array}{l}\text { It is important to develop educational curricula about } \\
\text { masturbation and it's risks? }\end{array}$ & 57 & 17.1 & 18 & 5.4 & 259 & 77.5 \\
\hline $\begin{array}{l}\text { Frequent practice of female to masturbation leads to } \\
\text { addiction and leave it difficult? }\end{array}$ & 75 & 22.5 & 87 & 26.0 & 172 & 51.5 \\
\hline
\end{tabular}




\section{Assessment of knowledge and attitude of married women regarding masturbation risks.}

Table (6): Distribution of relation between studied women total knowledge score and their general characteristics $(n=334)$.

\begin{tabular}{|c|c|c|c|c|}
\hline \multirow[t]{2}{*}{ Socio-demographic data } & \multirow[t]{2}{*}{ Mean \pm SD } & \multicolumn{2}{|c|}{ Statistical test } & \multirow{2}{*}{$\mathrm{P}$ value } \\
\hline & & F test & t.test & \\
\hline $\begin{array}{l}\text { Age in years } \\
20-29 \\
30-39 \\
40-50\end{array}$ & $\begin{array}{l}18.0311 \pm 3.25466 \\
16.4655 \pm 3.89522 \\
19.1930 \pm 2.81855\end{array}$ & 13.69 & & $<0.001^{* *}$ \\
\hline $\begin{array}{l}\text { Marital status } \\
\text { Married } \\
\text { Divorced } \\
\text { Widow }\end{array}$ & $\begin{array}{c}17.7370 \pm 3.69598 \\
17.0769 \pm .27175\end{array}$ & & 3.03 & $<0.001^{* *}$ \\
\hline $\begin{array}{l}\text { Years of marriage } \\
\text { Less than one year } \\
\text { (1-5 )years } \\
\text { More than } 5 \text { years }\end{array}$ & $\begin{array}{l}17.5397 \pm 2.76397 \\
18.5725 \pm 3.41947 \\
16.9214 \pm 3.81792\end{array}$ & 7.66 & & $<0.05^{*}$ \\
\hline $\begin{array}{l}\text { Educational level } \\
\text { Illiterate } \\
\text { Read and writ } \\
\text { Secondary } \\
\text { Graduate }\end{array}$ & $\begin{array}{l}15.6379 \pm 1.20959 \\
16.6610 \pm 5.41266 \\
18.4091 \pm 2.27246 \\
18.5814 \pm 3.44533\end{array}$ & 13.33 & & $<0.001 * *$ \\
\hline $\begin{array}{l}\text { Occupation } \\
\text { House wife } \\
\text { Craft woman } \\
\text { employer } \\
\end{array}$ & $\begin{array}{c}16.8571 \pm 4.16905 \\
14.0000 \pm .00000 \\
18.6250 \pm 2.79258\end{array}$ & 21.55 & & $<0.001^{* *}$ \\
\hline $\begin{array}{l}\text { Residence } \\
\text { Rural } \\
\text { Urban }\end{array}$ & $\begin{array}{l}17.2523 \pm 2.52039 \\
18.5446 \pm 4.91163\end{array}$ & & 2.61 & $<0.001^{* *}$ \\
\hline
\end{tabular}

Table (7): Distribution of relation between studied women total attitude score and + general characteristics $(n=334)$.

\begin{tabular}{|c|c|c|c|c|}
\hline \multirow[t]{2}{*}{ Socio-demographic data } & \multirow{2}{*}{ Mean \pm SD } & \multicolumn{2}{|c|}{ Statistical test } & \multirow{2}{*}{$P$ value } \\
\hline & & F test & t.test & \\
\hline $\begin{array}{l}\text { Age in years } \\
20-30 \\
30-40 \\
40-50\end{array}$ & $\begin{array}{l}27.4912 \pm 4.25157 \\
31.0776 \pm 3.77901 \\
31.3665 \pm 2.90407\end{array}$ & 27.77 & & $<0.001 * *$ \\
\hline $\begin{array}{l}\text { Marital status } \\
\text { Married } \\
\text { Divorced }\end{array}$ & $\begin{array}{c}36.0000 \pm .00000 \\
30.1494 \pm 3.54365\end{array}$ & & 28.97 & $<0.001 * *$ \\
\hline $\begin{array}{l}\text { Years of marriage } \\
\text { Less than one year } \\
1-5 \text { years } \\
\text { More than } 5 \text { years }\end{array}$ & $\begin{array}{l}29.3071 \pm 4.52951 \\
30.3588 \pm 2.17351 \\
34.0000 \pm 1.96748\end{array}$ & 43.31 & & $<0.05^{*}$ \\
\hline $\begin{array}{l}\text { Educational qualification } \\
\text { Illiterate } \\
\text { Read and writ } \\
\text { Secondary } \\
\text { Graduate } \\
\end{array}$ & $\begin{array}{l}32.0795 \pm 2.96424 \\
26.2881 \pm 4.04735 \\
30.2713 \pm 2.07196 \\
33.5000 \pm 3.29939 \\
\end{array}$ & 68.30 & & $<0.001 * *$ \\
\hline $\begin{array}{l}\text { Occupation } \\
\text { House wife } \\
\text { Craft woman } \\
\text { Employer } \\
\end{array}$ & $\begin{array}{c}30.0000 \pm 4.85393 \\
29.0000 \pm .00000 \\
31.1902 \pm 2.77611 \\
\end{array}$ & 5.69 & & $<0.05^{*}$ \\
\hline $\begin{array}{l}\text { Residence } \\
\text { Rural } \\
\text { Urban }\end{array}$ & $\begin{array}{l}30.2342 \pm 3.77046 \\
31.3393 \pm 3.60569\end{array}$ & & 2.60 & $<0.001 * *$ \\
\hline
\end{tabular}



risks.

Table (8): Distribution of correlation between studied women total knowledge and attitude score $(\mathrm{n}=334)$.

\begin{tabular}{|l|c|c|}
\hline \multirow{2}{*}{ Variables } & \multicolumn{2}{|c|}{ Total attitude score } \\
\cline { 2 - 3 } & $\mathrm{R}$ & P value \\
\hline Total knowledge score & $.417^{* *}$ & .000 \\
\hline
\end{tabular}

Correlation is significant at the 0.01 level (2-tailed).

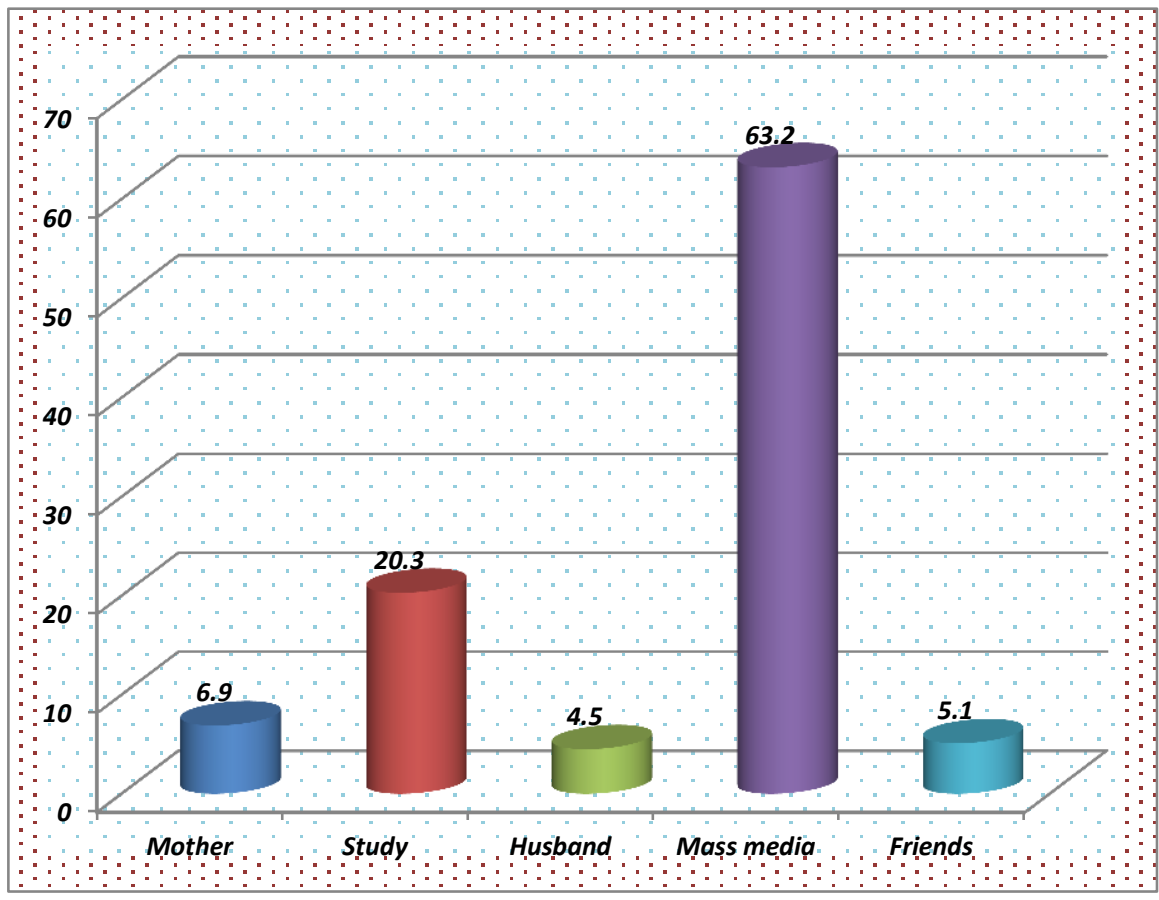

Figure (1)

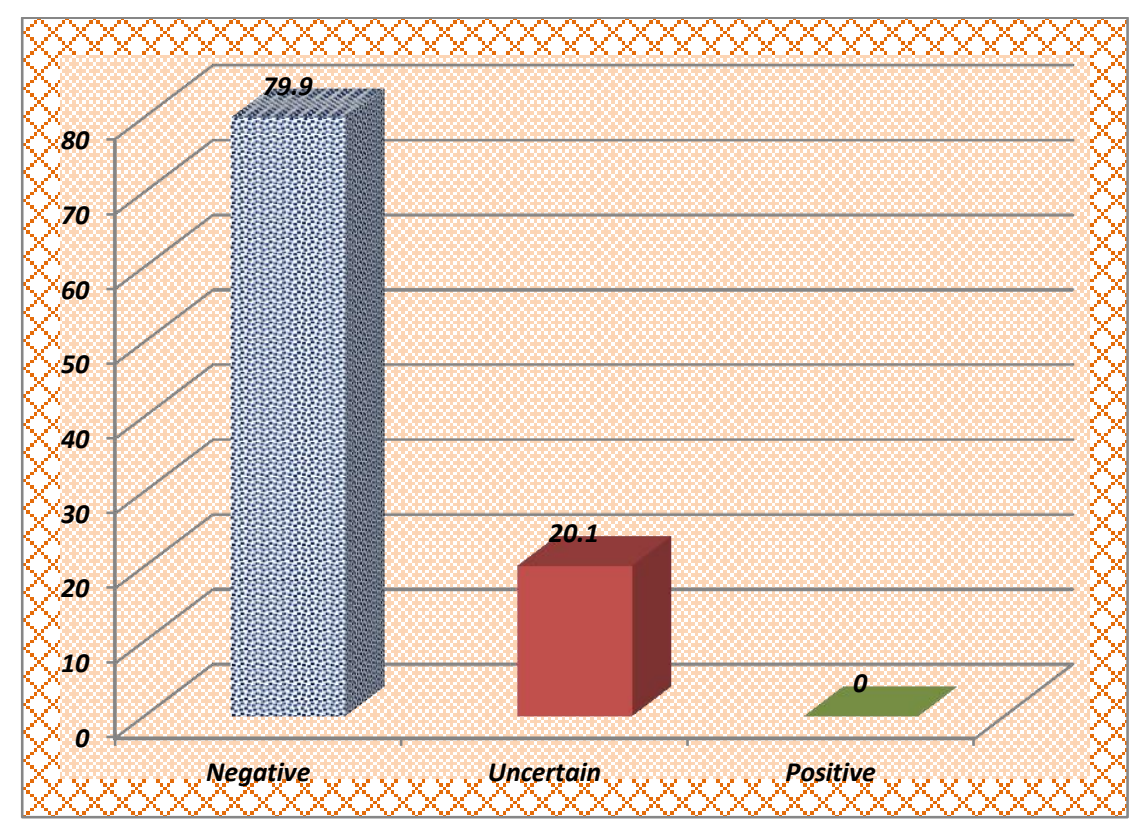

Figure (2)

\section{Discussion:}


Because of the sensitive nature of the topic, female masturbation is not common subject in the Egyptian nursing literature. The present study aimed to assess knowledge and attitude of married women regarding masturbation risks

In the current study, most of participants $(54.9 \%)$ had a moderate to high degree of education which means that the results were relatively accurate. As education makes persons more open minded and easy to deal with.

Regarding knowledge of the studied participant gain their knowledge about masturbation, the result of the present study reveals that; $(5.1 \%)$ of them gain from friends and This shows the great effect of beers on the knowledge and subsequently masturbation practices of children and adolescent the same result was obtained by Mark and David, (2014) who concluded that, girls learned about masturbation from friends (29.3\% of girls).

This result is agreed with Chi and Winter, (2012)) who found that The majority of our study participants reported that they first know about masturbation at early and middle adolescence. Mainly friends were the main sources of, information about masturbation. The majority of our study participants tried getting more information about masturbation, mainly from internet and friends

As regard masturbation practice, more than half of the participants $(66.5 \%)$ reported that each of male and female practice masturbation.

This agree with result were obtained by Klein, (2014) who report that $73 \%$ of male and $36.8 \%$ of female practice masturbation at the some point in their lives
Regarding the age of masturbation onset, More than half of participant $(60.2 \%)$ reported that the age of beginning of female practice masturbation was 20years old

Similarity with the result was obtained from the study of Egyptian female masturbation carried by Gunduzi et al., (2015) was between the age of 2029 about $44.2 \%$ admitted practice masturbation

The association between masturbation and higher educational level was confirmed by the results of Britain's second national survey of sexual attitudes and life styles in which, 50\% of females who had high degree of education were practiced masturbation compared to $24 \%$ of non-educated Females (Klein.,2014).

And there is agree with the result of Hungrige, (2016), Bowman, (2014) when reporting their findings, which included4762 British women stated that the more advanced education levels were linked to greater practice of masturbation

In the current study, more than half of females $(63.2 \%)$ gain their knowledge about masturbation through using mass media like internet and about (66.3\%)agree that the presence of mass media like videos and pictures with sexual insinuation lead to increase of masturbation practice.

This result is nearly similar to with Kasemy et al., (2016) who found a statistically positive correlation was observed between vaginal lubrication and positive watching. They found that when women were shown any type of pornography, they reported high level of sexual arousal and masturbation practice. Women's ability to imagine themselves as the women in the clips is an important factor strongly correlated with their reported arousal. 
Regarding the causes which make married women masturbated, the findings of the current study indicated that $(37.7 \%)$ of participants reported that is sexual Satisfaction(reach orgasm) which was observed to indicate a lack of sexual satisfaction with a women's sexual partner or un availability of husband either travelled or died.

There is agree with Carvalheira and Leal, (2013) who found fewer women reported masturbating 'for physical pleasure' $(42 \%)$, more women indicated because 'partner was unavailable' $(32 \%)$, a minority of women $(8.6 \%)$ reported that masturbation is used as a replacement for sexual activity, while it means an additional way to achieve sexual pleasure for the majority (65.4\%)

Regarding the question of the opinion of Islam regarding masturbation, found that $44,9 \%$ of participant who said that it's forbidden vs $20.7 \%$ who consider It is permissible in Islam.

These agree with Moawad, (2015) who found high significance statistical difference regarding the question of masturbation being forbidden as $52.9 \%$ of women versus $15.4 \%$ who consider masturbation is forbidden.

And this may be due to Egypt is an Islamic country, all aspects of sex, are organized by religious rules. Also, the conservative nature of the Egyptian society in general and that of women in particular may explain that. In Egypt some women are follow religious rules and consider masturbation is sinful and there for forbidden

As regard relation, it was found there was a highly positive relation between the studied women total knowledge score and their educational qualification. As the highest total knowledge mean score was among women with graduate level of education.

Regarding correlation, there was a highly positive association between the studied women total knowledge and attitude score .As it was found most of the studied women $(67.1 \%)$ had poor knowledge and (79.9\%) had negative attitude toward masturbation practice.

This may be due to Egypt is an Islamic country, all aspects of sex, are organized by religious rules ,in Egypt some women are follow religious rules and consider masturbation is sinful and there for forbidden.

\section{Conclusion}

Based on the overall finding of the present study, it can be concluded that more than half of studied women had poor knowledge regarding masturbation and its risks. On the other hand, majority of studied participants had negative attitude regarding masturbation risks. Conclusion of the current support research question and its aim. Therefore, the study question was answered.

\section{RECOMMENDATION}

\section{Recommendations were inferred from the study:-}

1) Educational program, including married women to raising awareness regarding masturbation risks.

2) The religious organization should play a more active role in educating the adolescents on sex education about masturbation and it's risks and their opinion related to masturbation.

3) Efforts must be taken to set up health centers and counseling unit to provide accessible services in order to control masturbation problems

4) The films and clips shown on different media should be censored 
5) The health care provider should give health education for clients to avoid and weaning from masturbation.

\section{References}

Bowman; 2013: women's masturbation: experiencesof sexual empowerment in a primarilysex-positive sample, Psychology of Women Quarterly,38(3):363-378.

Carvalheira, A\& Leal, I; 2013: Masturbation among women: Associated factors and sexual response in a Portuguese community sample. Journal of Sex \& Marital Therapy, 39(4), 347-367. doi: 10.1080/0092623X.2011.628440

Chi X., Yu L \& Winter.,(2012): Prevalence, S. (and correlates of sexual behaviors among university students: A study in Hefei, China. BMC Public Health, 12, 972-982.

Guttmacher Institute., (2015): Sex and HIV Education. State Policies in Brief. New York. Gutt masher Institute. Available at: http://www. guttmacher. org/ statecenter/ spibs/ spib SE.pdf.

Hungrige A., (2016): women's masturbation: an exploration of the influence of shame, guilt, and religiosity A dissertation submitted in partial fulfillment of the requirementsfor the degree of doctor of philosophy in the graduate school of theTexas woman's university

Kabbash I., Abo-Ali E.,Kabbash M and Abo El-Naga A.,(2017):Perception and practices of masturbation by male medical students, Tanta University, Egypt, The Egyptian Journal of Community Medicine .,35 (1),99-115

Klein J.,(2014): encyclopedia of social deviance Masturbation,: Encyclopedia of Social Deviance,Chapter

"Masturbation".

SAGE Publications,inc company, pp:424-427Avail at:https://www .researchgate.net/publication/308 400235

Mark Regnerus and David Gordon.,(2014):social, emotional, and relational distinctions in patterns of recent masturbation among young adults, Arch Sex Behavior,32(5):102-115.

Moawad L;2015: Self stimulation in women, thesis degree in dermatology and andrology ,faculty of Medicine ,Benha university. 